（3）窒素が牧草と雑草の競争に及ぼす影響は，牧草 および雑草の草型と窒素に対する反応によつて異なり， 窒素の増施によつて牧草が増加するとともに雑草が減少 する場合と，牧草の増加と並行して雑草も増加する場合 と, 牧草の増加をおさえて雑草が増加する場合とがみら れた。

（4）前作物が牧草と雑草の競争に及ぼす影響は，前 作物が 1 年だけでは明確でない場合が多いが，大豆より 玉蜀㯟が，馬鈴薯一家畜カブより陸稲・小豆が雑草の発 生が多い傾向が認められた。

本試験は文部省試験研究費「畑地輪作体系における牧 草とその前作物に関する試験研究」代表者 東北大学農 学部名誉教授 水島宇三郎博土の補助により実施した。 厚く御礼申し上げます。

\section{引 用 文 献}

1）酒井博・佐藤徳雄・藤原勝見：春播特よび秋播牧草に対する除草 剂の利用. 雑草研究 5，118 123 (1966).

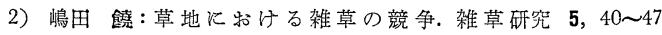
(1966).

3）関誠：春播に知けるレッドクローバーと雑草との競争試験. 亩産の研究 11 (11)，1361 1362; 12 (2)，323 324; 13 (4), 565 566; 14 (7), 949 950. (1957, 1958, 1959, 1960).

4) Blackman, G. E. and W. G. Templeman: Jour. Agr. Sci. 27 (2), 247 271 (1938).

5) Jorge N. H. and Staniforth.D. F.: Agron. J. .53, 1 5 (1961).

6) 桜井 輔：作付様式と雑草発生について. 東北農業 4 (5〜6) 314 $\sim 316$ (1951).

7）千坂英雄：水稻と雑草の競争. 雑草研究 5, 16 22 (1966).

8）鳥山国士・豊川良一：畑雑草の防除汇関与る研究。日作紀 25, 22 $\sim 23$ (1957).

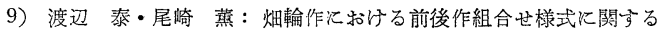
矿究. 北海 道農試彙報 83，53 63 (1964).

\title{
Influences of Preceding Crops and Nitrogen Fertilization on Weed Population in Pasture Grasses
}

Hiroshi SakaI, Tokuo Sato, Katsumi Fujiwara and Yoshiaki ŌBa Kawatabi Farm, Faculty of Agriculture, Tohoku University, Narugomachi, Miyagi

\section{Summary}

(1) Three cases were found by increasing of the nitrogen fertilization on forage grasses as follows:

(a) Orchardgrass seeded in autumn predominated over the weeds, (b) both spring seeded orchardgrass and weeds increased, and (c) in the case of radino-clover seeded in autumn or spring weeds increased more than the forage crop, by the increase of nitrogen fertilizer.

(2) The effects of preceding crops on weed population were also surveyed.

\section{スギナの 生態と防 除}

\author{
宮城県農業試験場古川分場 二瓶信男・佐々木亨・山崎慎一
}

スギナ1) (Equisetum arvense L.) は「とくさ科」に 属し, 畑はもちろん, 原野, 農道など至る所に発生する 多年生草本で, 地下茥は長く, 地中を深く横走している ため極めて防除困難で，現在のところ合理的な防除法は 少ない。

一方，近年のめざましい畑除草剤の普及により，これ までの優占雑草であつたメヒシバ，ハコベ，ナズナ等の 減少によつてスギナが年々増加し，優占化する傾向にあ
る。本県の畑地带でも発生が多くなり, 適切な防除法の 開発が要望されている。

よつて 1965 66 年にスギナの生態と防除法について 試験を行なつた。以下にその結果を報告する。

\section{1. スギナの生態}

\section{（1）胞子の発芽}

1) 試験方法: 直径 $6 \mathrm{~cm}$, 深さ $5.5 \mathrm{~cm}$ の小型素焼 
鉢に砂（直径 $2 \mathrm{~mm}$ 以下），腐植土および長さ $2 \mathrm{~cm}$ 前 後に切断した水苔を鉢詰めにし, 50 分間蒸気滅菌を行 ない，泠却後各々の鉢に胞子を接種（5月 7 日）し，上 部をシャーレで覆い，別に水を浅く入れた水盤を用意 し，鉢をこれに入れて常時吸水させ，室内に置いた2”。 温度は $15 \sim 25^{\circ} \mathrm{C}$ であった。

口）発芽生育経過：接種後 7 日目に一斉に発芽管が伸 び，13 日目に細い鱗片状の前葉体ができ（ただし水苔 を詰めた鉢では, 過湿のためか発芽せず), 日を経るにつ れてハート型に成長し，16日目頃には肉眼で観察でき るようになり，根も1 2 cm 亿伸長した。その後も前葉 体は生長したが，砂に接種した区は黄変して生育不良と なり，接種後 45 日目頃になると徐々に枯死し始めた。

よつて第 1 表に示した培養液を作り，鉢を移したとこ ろ, 生育が回復し, 次第に緑色となつて挽回した。しか， し腐植土には及ばな

第 1 表 培養液組成

かつた。

接種後 43 日目頃 になると，腐植土で は一斉に栄養茎が発 生したが，砂土では 5 日程遅れて発生し

\begin{tabular}{l|c}
\hline \multicolumn{1}{c|}{ 成 } & 含有量 $(\mathrm{g} / l)$ \\
\hline $\mathrm{KNO}_{3}$ & 0.81 \\
$\mathrm{Ca}\left(\mathrm{NO}_{3}\right)_{2} \cdot 4 \mathrm{H}_{2} \mathrm{O}$ & 0.95 \\
$\mathrm{MgSO}_{4} \cdot 7 \mathrm{H}_{2} \mathrm{O}$ & 0.50 \\
$\mathrm{NH}_{4} \mathrm{H}_{2} \mathrm{PO}_{4}$ & 0.155 \\
\hline $\mathrm{pH} 5.5 \pm 0.2$ & \\
\hline
\end{tabular}
た。なお前葉体は 7 月中旬より黄変枯死し始め, 7 月下 旬までにほとんどなくなつた。

胞子より生じ栄養茎は, 無性生殖により発生した栄 養茎に輪生する三角もしくは四角柱状の小枝と同様であ り，節は退化縮少した 3 4 つの舌状葉が「サヤ」状に ゆ着している。生育の初期は 1 本立ちのまま生長し続け るが， 8 月下旬から前述同様の栄養茎が地際から $2 \sim 4$ 本発生した。

その後生長し続け，8 月下旬頃になり栄養茎が 6 8 $\mathrm{cm}$ になると, 栄養茎の部分的な節より分枝を始めた が，輪生せず，普通 1 本だけである。この頃になると地 下茎も太く，暗褐色となり，5 10 cm 亿伸長し，10月 上旬になると横走した地下茎より栄養茎の発生をみた。

なお 10 月 29 日および栄養茎枯死後に生育調查を行な つたが, 栄養茎枯死後の調査では地下茎最長 $31.1 \mathrm{~cm}$, 総地下茎長 $65.6 \mathrm{~cm}$ となり，栄養繁殖同様のスギナとな つた。

\section{（2）地下茎の発根, 伸長}

$45 \times 45 \mathrm{~cm}$, 墚さ $55 \mathrm{~cm}$ の合成樹脂製の方形で, 一方 が透明プレートで発根状沉が観察できるポットに, 前年 度発生した地下茎の先端をむつ 3 節のものを 3 月 18 日 に植付けし, 覆土深 $5 \mathrm{~cm}, 7 \mathrm{~cm}$ の雨条件で検討した 結果, 両条件とも最初に前年より発生していた各節の細
根が活動し始め，4 月上旬になると頂部栄養茎が上方に 伸長し始めた。

4 月下旬から 5 月上旬にかけて各節より 2 3 本の栄 養茎加発生伸長し， 5 月中旬になると，やはり栄養茎の 発生した各節より下方に太い地下茥 (栄養茎, 地下茎の 発生能力を有するもの) が 2 3 本伸長し, その先端は 鋭く尖つたもので, 地下にやや直角に伸長しつつ各節よ り細根と栄養茎を発生し，また地下茎は分根し，6月末 にはポットの底まで達した。栄養茎が最も多く発生する のは地下 $30 \mathrm{~cm}$ 以内の地下茎からであり, これより深 くなるにつれて発生数は少なくなつた。

\section{（3）地下茎先端の発芽力}

3 月 18 日に 2,000 分の 1 a ポットに植付けし, これより発根してポットの底に達した地下茎の先端を有 する 3 節のものを直径 $8 \mathrm{~cm}$, 深さ $9 \mathrm{~cm}$ の小型ポット に砂（值径 $2 \mathrm{~mm}$ 以下）, 壤土, 埴土を詰めて植付け し, 上部をシャーレで覆い検討した。温度は $20 \sim 25^{\circ} \mathrm{C}$ であつた。結果は何れも $5 \sim 7$ 日後にその先端が伸び出 し, 完全な栄養茎となつた。

しかし, 地下茎の先端, 栄養茎の先端の判別が困難な ので，この区別については更に検討を要する。

\section{（4） 栄養茎からの発根}

7 月 18 日に栄養茎の先端のない一部を取り, 直径 8 $\mathrm{cm}$, 深さ $9 \mathrm{~cm}$ の小型ポットに砂耕区, 水耕区を設け 検討した結果，7１0日後になると各節より一斉に発根 し, 輪生状に密生する小枝の各節（退化縮少した舌状葉 がサヤ状にゆ着しているところ) からも発根した。

これらのことから，栄養茎はどの部分でも節 1 個をも つておれば発根できることがわかる。

\section{(5) 肥料要素と生育}

肥料住対する反応を知るため 2,000 分の 1 a ポット を使用し，供試土壤は沖積埴壌土で $\mathrm{P} \cdot \mathrm{K}$ 区， $\mathrm{N} ・ \mathrm{~K}$ 区, $N \cdot P$ 区， N P P $\mathrm{K}$ 区，無肥料区を設けた。 1 ポット当りの成分施用量は各々 $1 \mathrm{~g}$ で, 硫安, 過石, 塩加を使用し，3 月 15 日（植付け 3 日前) に施用した。 地下茎の植付けは 3 月:18日で, 先端をむつ 3 節のもの を1ポットに 3 本ゔつ植付けた。

結果は第 2 表に示した通りで, 最も生育の旺盛だつた 第 2 表 肥料要素々生育との関係 ( 7 月 8 日調查)

\begin{tabular}{|c|c|c|c|c|c|c|c|}
\hline 区 & |発生姶| & 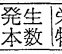 & 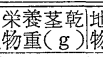 & 它下茄重( & $\begin{array}{l}\text { 全乾物電| } \\
(\mathrm{g})\end{array}$ & 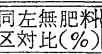 & $\mid \begin{array}{l} \pm \text { 塂 } \\
\mathrm{pH}^{*}\end{array}$ \\
\hline$P \cdot K \quad 区$ & $4 \cdot 26$ & 60 & 6.0 & 7.1 & 13.1 & 112 & 7.20 \\
\hline$N \cdot K$ & $4 \cdot 26$ & 124 & 15.5 & 16.3. & 31.8 & 272 & 6.05 \\
\hline$N \cdot P \quad 区$ & $4 \cdot 22$ & 129 & 17.0 & 13.5 & 30.5 & 261 & 6.31 \\
\hline$N \cdot P \cdot K 区$ & $4 \cdot 28$ & 88 & 13.0 & 12.3 & 25.3 & 216 & 7.42 \\
\hline 無肥料区 & $4 \cdot 21$ & 55 & 5.0 & 6.7 & 11.7 & 100 & 7.30 \\
\hline
\end{tabular}

\footnotetext{
* 5 月10日調查
} 
区は $\mathrm{N} ・ \mathrm{~K}$ 区, $\mathrm{N} ・ \mathrm{P}$ 区であり, 栄養茎, 地下茎と もに良い生育を示した。 $\mathrm{N} ・ \mathrm{P} ・ \mathrm{~K}$ 区も良い生育を示 したが，僅かに $\mathrm{N} ・ \mathrm{~K}$ 区， N・P 区に劣つた。

最も生育の悪かつたのは無肥料区であり，次いで $\mathrm{P} ・$ K区で，無肥料区と大差はなかつた。以上のように，ス ギナの生育は N により最も影響を受けることがわかつ た。

しかし, 以上の生育は $\mathrm{pH}$ の強弱と関係した生育を示 しており，これを考慮した場合，かならずしも肥料要素 によるものとは言い切れず，更に $\mathrm{pH}$ の規正条件で検討 の必要がある。よつて次の実験をこころみた。

\section{（6） $\mathbf{p H}$ と生育}

$\mathrm{pH}$ に対する限界を知るため, $\mathrm{pH}\left(\mathrm{H}_{2} \mathrm{O}\right) 7.25$ ～ 7.30 の沖積埴畩土を使用し, これに $\mathrm{pH}$ 規正のため石灰およ び硫黄華を加えて攪挥し， 2,000 分の 1 a ポットに詰 め，5 日後に地下茎の先端を有する 3 節のものを 1 ポッ ト当り 3 本づつ 3 月 18 日に植付け， $5 \mathrm{~cm}$ の覆土を行 ない検討した。試験中の $\mathrm{pH}$ 測定結果は第 3 表の通りで ある。

第 3 表 $\mathrm{pH}$ 調 查

\begin{tabular}{|c|c|c|c|c|c|c|}
\hline & \multicolumn{3}{|c|}{4 月 3 日 } & \multicolumn{3}{|c|}{5 月 10 日 } \\
\hline & & & |置換酸度 & & & |瞐換酸度 \\
\hline & $\mathrm{H}_{2} \mathrm{O}$ & $\mathrm{KCl}$ & $y_{1}$ & $\mathrm{H}_{2} \mathrm{O}$ & $\mathrm{KCl}$ & $y_{1}$ \\
\hline 硫黄華 $80 \mathrm{~g}$ 区 & 7.01 & 5.90 & 0.20 & 4.47 & 3.90 & 6.71 \\
\hline 》 $50 \mathrm{~g}$ 区 & 7.02 & 5.83 & 0.20 & 4.65 & 4.05 & 4.83 \\
\hline 》 $20 \mathrm{~g}$ 区 & 7.00 & 5.83 & 0.25 & 5.09 & 4.38 & 1.98 \\
\hline 無 加 用 区 & 7.25 & 5.90 & 0.15 & 7.30 & 6.16 & 0.86 \\
\hline 石灰 $119 \mathrm{~g}$ 区 & 9.30 & 8.52 & - & 9.00 & 8. 10 & 0 \\
\hline
\end{tabular}

結果は第 4 表に示すように， $\mathrm{pH}$ 規正が完全でないた め，詳細について述べることは出来ないが，本試験では $\mathrm{pH}\left(\mathrm{H}_{2} \mathrm{O}\right) 7$ 前後の無加用区の生育が優つた。しかし 栄養茎の黄変が認められ，生育は完全でないことから， スギナの最適 $\mathrm{pH}$ はこれ以下 (酸性) にあると考えられ る。硫黄華加用区では，5 月 10 日の $\mathrm{pH}$ が 5 4 に低

第 4 表 $\mathrm{pH}$ と生育との関係

\begin{tabular}{|c|c|c|c|c|c|}
\hline 区 & $\begin{array}{c}\text { (発芽始 } \\
\text { (月) }\end{array}$ & 発生本数 & $\begin{array}{l}\text { 栄美蓕鄣 } \\
\text { 物重 }(\mathrm{g})\end{array}$ & $\begin{array}{l}\text { 地下菱乾 } \\
\text { 物重 }(\mathrm{g})\end{array}$ & $\begin{array}{c}\text { 全乾物重 } \\
(\mathrm{g})\end{array}$ \\
\hline 硫黄華 $80 \mathrm{~g}$ 区 & - & 0 & 0 & 0 & 0 \\
\hline ” $50 \mathrm{~g}$ 区 & $5 \cdot 6$ & 0 & 0 & 0 & 0 \\
\hline " $20 \mathrm{~g}$ 区 & $4 \cdot 24$ & 11 & 1.0 & 0.8 & 1.8 \\
\hline 無 加 用 区 & $4 \cdot 24$ & 45 & 3.5 & 1.5 & 5.0 \\
\hline 石灰 $119 \mathrm{~g}$ 区 & $4 \cdot 23$ & 6 & 1.5 & 1.0 & 2.5 \\
\hline
\end{tabular}

下してもスギナは全く発生しなかつた。これは他の雑草 も全々発生しないことからみて, 硫黄華による薬害と考 えられる。また石灰加用区についてみると, 極めて生育 が劣り，1区は発芽後間もなく黄変枯死し，他の 1 区も 発芽後ほとんど枯死し, 残存した栄養茎も生育が極めて
悪く，辛うじて枯死しない程度であり，したがつて地下 茎も細く貧弱であつた。以上からスギナの $\mathrm{pH}$ (アルカ リ側）限界は 9.0 前後にあると考えられる。

\section{(7) 発生深度と生育}

2,000 分の 1 a ポットを使用し, これに埴壤土の $\mathrm{pH}\left(\mathrm{H}_{2} \mathrm{O}\right) 7.3$ 前後の土を詰め，3 月 18 日に地下茎の 先端を有する 3 節のものを 1 ポット当り 3 本づつ植付け し，覆土深 $5,10,15,20 \mathrm{~cm}$ の 4 条件で検討した。な お試験中の $\mathrm{pH}\left(\mathrm{H}_{2} \mathrm{O}\right)$ は 4 月 3 日で 7.25，5月 10 日 で 7.30 であつた。

結果は第 5 表の通りで, 発芽は各区とも大差なく, 相 当深いところからも発芽能力をもつている。しかし植付 けした地下茎が 3 節を有するものでも覆土が深くなるに

第 5 表 発生深度と生育との関係

\begin{tabular}{|c|c|c|c|c|c|c|}
\hline \multirow{2}{*}{ 覆土深 $(\mathrm{cm})$} & \multirow{2}{*}{$\begin{array}{l}\text { 発芽始 } \\
\text { (月・日) }\end{array}$} & \multicolumn{2}{|c|}{ 発生 本 数 } & \multirow{2}{*}{$\begin{array}{c}\text { 栄美菱 } \\
\text { 乾物 } \\
(\mathrm{g})\end{array}$} & \multirow{2}{*}{$\begin{array}{c}\text { 地下蓄 } \\
\text { 乾物毫 }\end{array}$} & \multirow{2}{*}{$\begin{array}{c}\text { 全乾物重 } \\
(\mathrm{g})\end{array}$} \\
\hline & & 6 月 1 日 & 7月 8 日 & & & \\
\hline 5 & $4 \cdot 24$ & 20 & 54 & 9.5 & 16.5 & 26.0 \\
\hline 10 & $5 \cdot 4$ & 3 & 70 & 5.5 & 8.2 & 13.7 \\
\hline 15 & $5 \cdot 4$ & 1 & 40 & 4.0 & 3.5 & 9.5 \\
\hline 20 & $5 \cdot 4$ & 1 & 20 & 1.5 & 1.0 & 2.5 \\
\hline
\end{tabular}

注）乾物重はすべて 7 月 8 日調査のもの

つれ栄養茎, 地下茎の生育は劣り, 特に $15 \mathrm{~cm}, 20 \mathrm{~cm}$ 区の地下茥の発育が悪く, 細かつた。したがつて本試験 では，生育量等からみて $5 \sim 10 \mathrm{~cm}$ 下層が生育に適する 深さと考えられるが，大きな地下茎を植付けた場合は栄 養源が大となるので，こらした場合等について更に検討 を要する。

\section{（8）土の種類と生育}

猿土, 砂土, 火山灰土を供試し, 2,000 分の 1 a ポ ットに詰め, 3 月 18 日に先端を有する 3 節の地下茎を 植付け， $5 \mathrm{~cm}$ の覆土を行なつた。結果は第 7 表の通り である。

初期生育は砂土が最も良く, 壌土, 火山灰土は劣つた が生育後半から旺盛な生育となり, 栄養茎は各土壤とも 第 6 表 $\mathrm{pH}$ 調 查

\begin{tabular}{|c|c|c|c|c|c|c|}
\hline \multirow{2}{*}{ 条 件 } & \multirow{2}{*}{\multicolumn{2}{|c|}{4 月 3}} & 日 & \multicolumn{3}{|c|}{5 月 10 日 } \\
\hline & & & |冝換酸度 & 1 & & 置換酸度 \\
\hline & 6.70 & 5.60 & 0.25 & $\frac{\mathrm{H}_{2} \mathrm{O}}{7.30}$ & 6.03 & 0.61 \\
\hline 砂 & 5.01 & 3.95 & 6.50 & 5.60 & 4.40 & 6.10 \\
\hline 火山灰土 & 5.23 & 4. 40 & 1.32 & 6.15 & 4.78 & 1.47 \\
\hline
\end{tabular}

第 7 表 土壌の種類と生育との関係

\begin{tabular}{|c|c|c|c|c|c|c|}
\hline 土猿の種類 & $\begin{array}{l}\text { 登芽始 } \\
(\text { 月・日 }\end{array}$ & \multicolumn{5}{|c|}{ 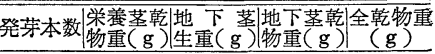 } \\
\hline 壤 & $4 \cdot 23$ & 62 & 7.5 & 122.0 & 17.0 & 22.5 \\
\hline 砂 & $4 \cdot 21$ & 75 & 8.3 & 30.8 & 9.3 & 17.6 \\
\hline 火山灰土 & $4 \cdot 22$ & 51 & 6.3 & 110.3 & 12.7 & 19.0 \\
\hline
\end{tabular}


同等の生育状況となつた。

地下茥で注土が劣り, 壤土, 火山灰土の 3 分の 1 と なつた。結果は壌土, 火山灰土, 砂土の順となつたが, スギナの生育には土中の養分, $\mathrm{pH}$ なども関係すると考 えられる。

\section{（9）地下茎の繁殖力}

スギナは地下茎による無性繁殖が大きいと考えられる が，地下茎が年間の生育期間にどれほど増加するかにつ いて, $45 \times 45 \mathrm{~cm}$, 深さ $55 \mathrm{~cm}$ のポットに $\mathrm{pH}\left(\mathrm{H}_{2} \mathrm{O}\right)$ 7. $25 \sim 7.30$ 前後の沖積埴壤土を詰め, これに先端を有 する 3 節の地下茎 (重量 $2 \sim 3 \mathrm{~g}$, 長さ $5 \sim 10 \mathrm{~cm}$ ) 6 本 を 3 月 18 日に植付けし, 覆土深 $5 \mathrm{~cm}, 7 \mathrm{~cm}$ で調查し た。結果は第 8 表の通りである。

第 8 表 地下茎調査

\begin{tabular}{|c|c|c|c|}
\hline 覆土深 ${ }^{\text {項 }}$ & $\begin{array}{c}\text { 地下䔲総生重 } \\
(\mathrm{g})\end{array}$ & $\begin{array}{c}\text { 同左乾物重 } \\
(\mathrm{g})\end{array}$ & $\begin{array}{c}\text { 地下茎の長さ } \\
(\mathrm{cm})\end{array}$ \\
\hline $5 \mathrm{~cm}$ 覆 土 & 553 & 181 & $8,728.8$ \\
\hline $7 \mathrm{~cm}$ 覆土 & 488 & 141 & $7,924.3$ \\
\hline
\end{tabular}

すなわち地下茎は， 3 月中旬から 10 月中旬までの 7カ 月間に, 地下茎総生重で 33 37 倍, 長さで 165 182 倍となり, 根箱全体に発根し, 著しい増加を示した。し たがつてポットが大きい場合, また䧃場等の場合には更 に増加量が大となることが考えられる。

\section{2. スギナの防除法}

\section{(1) 防除試験}

効果があると考えられた第 9 表の除草剤について, ス ギナの優占戋場を供試し, 除草効果, 薬害調查を行なつ た。除草剤の散布は 7 月 5 日で, 気象条件は 7 月 4 日か

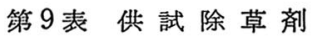

\begin{tabular}{|c|c|c|c|}
\hline 除草剂名 & $\begin{array}{c}\text { 成 分 } \\
(\%)\end{array}$ & 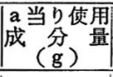 & 嚾 \\
\hline リニュロン水和郕 & 50 & 10 & \multirow{6}{*}{$\begin{array}{l}\text { この単郕と, これに各々 } 2,4- \\
\text { D ーダ塩 a 当り成分 } 20 \mathrm{~g} \\
\text { 混合した沉ついて検討 } \\
\text { た。 }\end{array}$} \\
\hline ブロメトリン水和刘 & 50 & 10 & \\
\hline ATA 水和剂 & 90 & 20 & \\
\hline ブロマシル水和㨈 & 80 & & \\
\hline BV-201＼cjkstart乳 & 25 & 30 & \\
\hline 2,4-D ソーダ塩: & 90 & $10,20,40$ & \\
\hline
\end{tabular}

ら9日までほとんど降雨があり（合計 $93 \mathrm{~mm}$ ), 条件は 良くなかつた。除草効果の調查は 7 月 16 日に行なつた。 結果は第 10 表の通りである。

すなわち単剤で最も効果の高かつたのは 2,4-D ソー 多塩であり, 量が多いほど効果が大で, 各量とも散布後 5 日前後で栄養茎は枯死したが，その後僅かに再生がみ られた。次いで ATA 水和剤の $40 \mathrm{~g}$, ブロマシル水和 剂の $40 \mathrm{~g}$ である。ATA ではほとんど枯死し, 残存し
第10表 訆 験 結 果 ( $\mathrm{m}^{2}$ 当り)

\begin{tabular}{|c|c|c|c|c|}
\hline 险草剂名 & $\begin{array}{ll}\text { 而 } \quad \text { 目 } \\
\end{array}$ & 発生栙敞 & 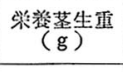 & 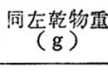 \\
\hline リニュロン水和郕 & $10 \mathrm{~g}$ & 292 & 783.3 & 175.0 \\
\hline " & 15 & 425 & 891.7 & 225.0 \\
\hline プロメトリン永䀅郕 & 10 & 308 & 804.2 & 191.7 \\
\hline " & 15 & 483 & 920.8 & 208.3 \\
\hline ATA 水和剂 & 20 & 333 & 966.7 & 233.3 \\
\hline " & 40 & 167 & 458.3 & 116.7 \\
\hline ブロマシルス和鼡 & 10 & 483 & $1,012.5$ & 233.3 \\
\hline " & 40 & 442 & 558.5 & 137.5 \\
\hline B V-201 昰 剂 & 30 & 317 & 725.0 & 213.3 \\
\hline " & 50 & 375 & 766.7 & 191.6 \\
\hline $2,4-\mathrm{D} ソ-\zeta$ 嫶 & 10 & 50 & 15.0 & 3.3 \\
\hline " & 20 & 33 & 10.8 & 2.5 \\
\hline "I & 40 & 17 & 8.3 & 1.9 \\
\hline 無 & 理 & 333.0 & 616.7 & 137.5 \\
\hline
\end{tabular}

た栄養䔄も黄変し生育抑制を受けたが，地下茥からの再 生がみられた。ブロマシルは除草効果が遅れ，7 月下旬 から 8 月にかけて徐々に枮死し始め, 效果は ATA の $40 \mathrm{~g}$ と同程度となつたが, 再生は ATA より多かつ た。しかし ATA では処理後の他の雑草の発生が多かつ た。これら以外の単剂区では，何れも散布後に生育抑 制, 栄養茎の先端枯死がみられたが，閒もなく回復し，
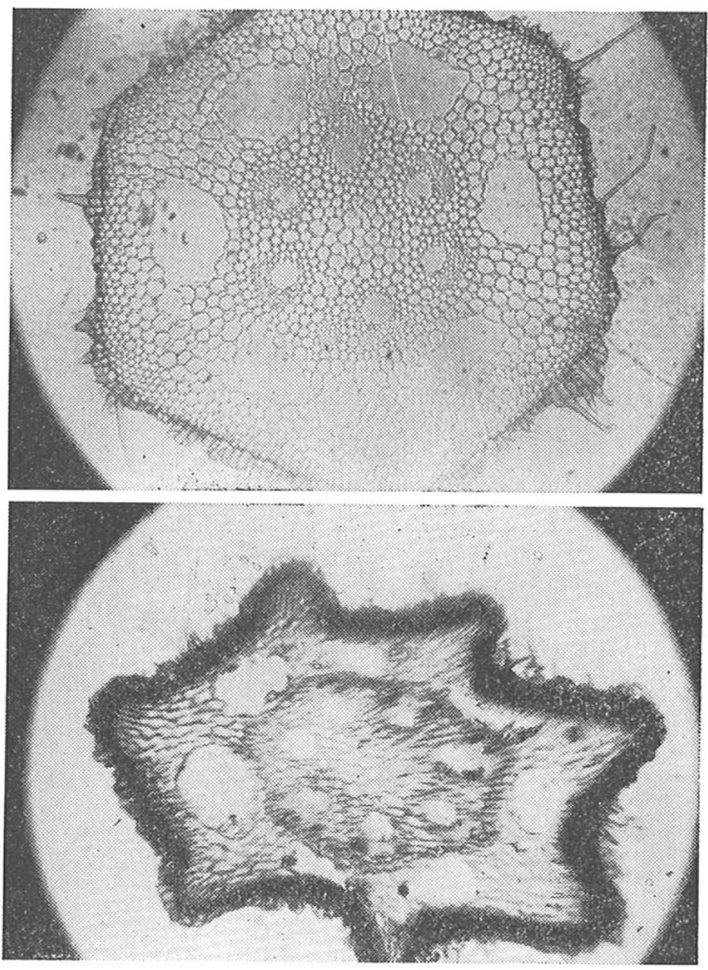

第 1 図 健全な地下茎と除草剤散布により 枯死した地下茎の横断面

上: 健全地下茎, 下: 除草䨩 (リニュロン $10 \mathrm{~g}+2,4-\mathrm{D} 20 \mathrm{~g}$ ) を散布した地下茎 
除草效果はほとんどみられなかつた。

次に 2,4-D ソーダ塩の混合㶡についてみるに, リニ ニロン $+2,4-\mathrm{D}(10+20$ および $15+20$; 単位 $g$, 以下 同じ)，プロメトリン +2,4-D（10+20 および $15+20)$, $\mathrm{ATA}+2,4-\mathrm{D}(20+20$ および 40+20), ブロマシル+ 2,4-D (10+20 および 40+20), BV 201+2,4-D (30 +20 および $50+20)$ の各除草剤とも 5 7日後には栄 養茎が枯死し, その後徐々に地下茎も枯死（地下 15 $20 \mathrm{~cm}$ ) して 10 月末になつても全々再生はなく, また他 の雑草も発生しなかつた。

以上のように, 移行型除草剤とホルモン型の $2,4-\mathrm{D}$

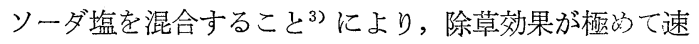
効となり, 天候が良ければ処理後 1〜2 日で栄養茥が枯 死し，また地下茎も枯死して全々再生がなく，防除は完 全である。

また栄養茎切除後散布, 耕耘後散布, 月別散布等につ いて予備試験を行ない（観察調査によつた），検討した が，除草効果を高めるには，栄養茎が最大でしかも気温 の高い $6,7,8$ 月の散布が合理的である。9 月以後の 散布では效果が遅れ，しかも除草效果は完全ではなかつ た。

\section{(2) 薬害調 査}

防除試験で效果の高かつた除草剂について大豆（品種 ウゴダイズ)，陸稲（品種 農林 14 号）を 7 月 28 日に播 種し， $3 \mathrm{~cm}$ の覆土後各々の除草剤を小型加圧噴霧器で 全面散布し, 調查した。なお，供試した畑土埛主は沖積埴 壤土である。

第 11 表のよらに，スギナに対して効果の高いものは， ATA を除いては薬害が著しく，ほとんど発芽せず，

第11表 薬害調査結果

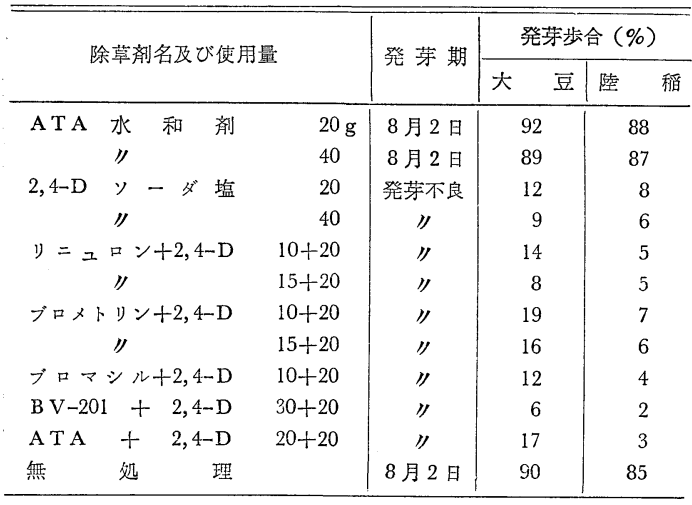

発芽, 生長した陸稲, 大豆は渏形となり，播種後の土䘫 処理としては使用できないようである。

ATA の単剤区については各量とも薬害が見られず, 陸稲, 大豆何れす無処理同栐に良好であつた。

\section{（3）麦に対する前記薬剤の効果}

次に, 前記薬剤を使用し, 1965 年に, 麦の生育ステージ と防除法についての次の試験它実施した。

イ）試験方法：怨理条件は第 12 表の通りである。た 第12表 処 理 条 件

\begin{tabular}{|c|c|c|}
\hline 処 理 時 期 & 除草剤名 & $\mathrm{a}$ 当り使用量 (成分 $\mathrm{g}$ ) \\
\hline 播 種 直 後 & $\begin{array}{c}\text { リニュロン+2, 4-D } \\
\text { プロマシル+2, 4-D } \\
\mathrm{AT} \mathrm{A}\end{array}$ & $\begin{array}{c}10+20 \\
10+20 \\
40\end{array}$ \\
\hline スギナ発生始期 & $\begin{array}{c}y=ュ \text { ロソ+2, 4-D } \\
\text { ブロマンル } 2,4-\mathrm{D} \\
\text { A T A }\end{array}$ & $\begin{array}{c}10+20,15+20 \\
10+20,20+20 \\
40\end{array}$ \\
\hline スギナ発生盛期 & $\begin{array}{c}リ=ュ ロ ン+2,4-\mathrm{D} \\
\text { ブロマシル+2,4-D } \\
\mathrm{AT} \mathrm{A}\end{array}$ & $\begin{array}{c}10+20,15+20 \\
10+20, \quad 20+20 \\
40\end{array}$ \\
\hline 麦刈取り15日前 & $\begin{array}{c}y=ュ \text { ロン+2, 4-D } \\
\text { プロマンル+2, 4-D } \\
\text { A T A }\end{array}$ & $\begin{array}{c}10+20,15+20 \\
10+20,20+20 \\
40\end{array}$ \\
\hline
\end{tabular}

だし除草剤は水和剤を使用し，各薬剤の成分はリニ二、ロ ン $50 \%, 2,4-\mathrm{D}$ ソーダ塩 $90 \%$, ATA $90 \%$, ブロマ シル $80 \%$ で， a 当り $10 l$ の水に溶かし, 小型加圧噴 霧器で, 麦生育期処理は畦間および株元に均一に散布し た。

散布月日は, 播種直後処理区は 10 月 11 日, スギナ発 生始期処理区 32 月 25 日，スギナ発生盛期処理区は 5 月 15 日（麦出穗期後 12 日），麦刈取り 15 日前処理区 は 6 月 1 日で，1区 $3.45 \mathrm{~m}^{2}$ の 2 区制とした。供試品 種は大麦のはがねむぎで，10月 7 日に播種し，他は標 準耕種梗概に準じた。途中の生育は, 病害その他の障害 もなく順調であつた。

口）試験結果：結果は第 13 表の通りである。播種後 処理では，ATA $40 \mathrm{~g}$ 区は初期に葉が部分的に黄白化し たが徐々に回復し，その後の生育は良好であり，成熟期 における各形質, 収量ともに手取り区に優つた。またり ニニロン $10 \mathrm{~g}+2,4-\mathrm{D} 20 \mathrm{~g}$ 区は初期葉がロールする薬 害がみられ，生育の抑制が若干後期の生育に影響した。 ブロマシル $10 \mathrm{~g}+2,4-\mathrm{D} 20 \mathrm{~g}$ 区は 11 月下旬に麦が黄 変して枯死し始め，12月には全部枯死するほど薬害が 著しかつた。

スギナ発生始期では，ATA $40 \mathrm{~g}$ 区，ブロマシル 20 $\mathrm{g}+2,4-\mathrm{D} 10 \mathrm{~g}$ 区ともに薬害为大きく, 大半は枯死し た。またブロマシル $10 \mathrm{~g}+2,4-\mathrm{D} 20 \mathrm{~g}$ 区も葉が一部枯 死し, 穂揃いが極めて悪く, 成熟期も著しく遅れ, 収量 は低下した。リニニロン+2,4-D 区のうち $15 \mathrm{~g}+20 \mathrm{~g}$ 区はやや生育抑制気味で, 収量は $10 \mathrm{~g}+20 \mathrm{~g}$ 区に劣 り，スギナ発生始期の処理としては $10 \mathrm{~g}+20 \mathrm{~g}$ 区が薬 害が認められず，生育も良好であつた。 
二瓶・佐々ホ・山崎：スギナの生態と防除

第13表 生育 - 収 量調 查

\begin{tabular}{|c|c|c|c|c|c|c|c|c|c|c|c|c|}
\hline \multirow{2}{*}{$\begin{array}{l}\text { 処理 } \\
\text { 時期 }\end{array}$} & \multirow[b]{2}{*}{ 姏理条化 } & & \multirow{2}{*}{$\begin{array}{l}\text { 発芽 } \\
\text { 息 } \\
\text { 良 }\end{array}$} & \multirow{2}{*}{$\begin{array}{l}\text { 出穂期 } \\
\text { (月・日) }\end{array}$} & \multirow{2}{*}{$\begin{array}{l}\text { 成熟期 } \\
\text { (月・日) }\end{array}$} & \multicolumn{3}{|c|}{ 成熟期飞打ける } & \multicolumn{3}{|c|}{$a$ 当り収穫量 } & \multirow{2}{*}{$\begin{array}{l}\text { 李察霜無 } \\
\text { 处球比 } \\
(\%)\end{array}$} \\
\hline & & & & & & ${ }^{\text {秙 }}(\mathrm{cm})^{\text {長 }}$ & 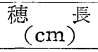 & $\mid \begin{array}{l}\mathrm{m}^{2} \\
\text { 穂 }\end{array}$ & $(\mathrm{kg})^{\text {盢 }}$ & $\begin{array}{l}\text { 子赛 重 } \\
(\mathrm{kg})\end{array}$ & $\begin{array}{l}\text { 㾑粒 雴 } \\
(\mathrm{kg})\end{array}$ & \\
\hline \multirow{3}{*}{$\begin{array}{l}\text { 播 } \\
\text { 種 } \\
\text { 後 }\end{array}$} & \multirow{3}{*}{$\begin{array}{c}\text { リュュッン+2, 4-D } \\
\text { ブロマシル } \\
\text { A T A }\end{array}$} & $(10+20)$ & 息 & $5 \cdot 6$ & $6 \cdot 11$ & 93.8 & 4.9 & 376 & 108.4 & 41.5 & 0.6 & 113 \\
\hline & & $(10+20)$ & "y & 䓴変 & 枯死 & & & & & & & \\
\hline & & $(40)$ & ") & $5 \cdot 3$ & $6 \cdot 11$ & 97.2 & 4.8 & 465 & 129.8 & 47.5 & 0.7 & 129 \\
\hline \multirow{5}{*}{ 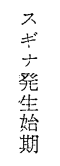 } & \multirow{5}{*}{ 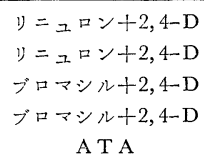 } & $(10+20)$ & 良 & $5 \cdot 2$ & $6 \cdot 11$ & 93.8 & 4.7 & 435 & 114.3 & 47.4 & 0.6 & 129 \\
\hline & & $(15+20)$ & ") & $5 \cdot 2$ & $6 \cdot 11$ & 91.7 & 4.5 & 317 & 110.0 & 41.5 & 0.3 & 113 \\
\hline & & $(10+20)$ & ") & $5 \cdot 2$ & $6 \cdot 18$ & 89.7 & 4.3 & 288 & 68.0 & 24.5 & 0.5 & 67 \\
\hline & & $(20+20)$ & " & 枯死 & 枯死 & & & & & & & \\
\hline & & (40) & " & 枯死 & 枮死 & & & & & & & \\
\hline \multirow{5}{*}{ 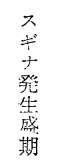 } & \multirow{5}{*}{$\begin{array}{c}y=ュ \text { ロ }+2,4-\mathrm{D} \\
y=ュ \text { ロ }+2,4-\mathrm{D} \\
\text { ブロマシル+2,4-D } \\
\text { ブロマシル+2.4-D } \\
\mathrm{ATA}\end{array}$} & $(10+20)$ & 息 & $5 \cdot 2$ & $6 \cdot 12$ & 92.5 & 4.7 & 370 & 98.6 & 37.6 & 0.6 & 102 \\
\hline & & $(15+20)$ & ") & $5 \cdot 2$ & $6 \cdot 12$ & 92.8 & 4.6 & 305 & 92.0 & 29.4 & 0.4 & 80 \\
\hline & & $(10+20)$ & ") & $5 \cdot 2$ & $6 \cdot 12$ & 93.0 & 4.5 & 317 & 94.4 & 35.4 & 0.6 & 96 \\
\hline & & $(20+20)$ & " & $5 \cdot 2$ & $6 \cdot 15$ & 94.2 & 4.5 & 320 & 103.3 & 36.5 & 0.8 & 99 \\
\hline & & $(40)$ & " & $5 \cdot 3$ & $6 \cdot 10$ & 93.8 & 4.5 & 361 & 110.0 & 45.1 & 0.4 & 123 \\
\hline \multirow{7}{*}{ 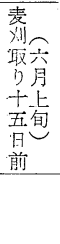 } & \multirow{5}{*}{$\begin{array}{c}y=ュ \text { ロン+2, 4-D } \\
y=ュ \text { ロ +2, 4-D } \\
\text { ブロマシル+2,4-D } \\
\text { ブロマシル+2,4-D } \\
\mathrm{ATA}\end{array}$} & $(10+20)$ & 良 & $5 \cdot 2$ & $6 \cdot 10$ & 94.4 & 4.4 & 400 & 111.3 & 42.3 & 0.4 & 115 \\
\hline & & $(15+20)$ & "y & $5 \cdot 2$ & $6 \cdot 10$ & 93.1 & 4.4 & 379 & 109.4 & 35.1 & 0.3 & 98 \\
\hline & & $(10+20)$ & ") & $5 \cdot 2$ & $6 \cdot 10$ & 91.8 & 4.4 & 284 & 95.4 & 34.2 & 0.3 & 93 \\
\hline & & $(20+20)$ & ") & $5 \cdot 2$ & $6 \cdot 10$ & 92.4 & 4.4 & 329 & 100.0 & 37.3 & 0.4 & 101 \\
\hline & & $(40)$ & " & $5 \cdot 1$ & $6 \cdot 11$ & 90.6 & 4.4 & 299 & 92.9 & 33.2 & 0.5 & 90 \\
\hline & 無 & 理 & 良 & $5 \cdot 2$ & $6 \cdot 10$ & 89.5 & 4.4 & 293 & 108.0 & 36.8 & 0.8 & 100 \\
\hline & 手 & 取 & 良 & $5 \cdot 4$ & $6 \cdot 11$ & 94.1 & 4.6 & 406 & 117.0 & 46.3 & 0.3 & 126 \\
\hline
\end{tabular}

スギナ発生盛期処理は，麦の出穂期約 10 日後の処理 であり，その時期までに発生したスギナ以外の雑草（八 コベ，ナズナ，スズメノテッポウ等）の影響も考慮され るが，ブロマシル $+2,4-\mathrm{D}$, リニュロン $+2,4-\mathrm{D}$ の各区 は，若干ではあるが薬剤による生育抑制により出穂期が 1日ほど遅れ, 収量もやや劣つた。しかし ATA $40 \mathrm{~g}$ 区は薬剤の影響が少なく，成熟も順調で，収量は手取り 区と同等であつた。

麦刚取り前 15 日処理では, 各処理区とも畦間をうつ閉 するほど雑草（ハコベ，ナズナ，スズメノテッポウ）が 繁茂したため, 雑草による養分収奪が大きく, 無処理区 の生育と同程度で, 成熟期が 1 日程度早まり, 収量も少 なかつた。リニニロン $15 \mathrm{~g}+2,4-\mathrm{D} 20 \mathrm{~g}$ ，ブロマシル +2,4-D, ATA の各区は薬剤散布によつて僅かではめ るが茎葉が黄白化気味であつたが, 成熟期も終りに入つ てからの処理なので，登熟に対する影響極めて小さい ものと考えられる。

八）考察：スギナの薬剤防除試験の結果から，スギナ の除草効果考高めるためには, 栄養茥が最大でしかも気 温の高い時期がよいとされている。これらのことよりみ れば，麦畑のスギナ防除にはスギナの発生盛期（5月15 日頃）から麦刚取り前 15 日頃（6月1日頃）までの閒 に $\mathrm{a}$ 当り，リニニロン $10 \mathrm{~g}+2,4-\mathrm{D} 20 \mathrm{~g}$ の混合剤を散 布するのがよい。跡作に大豆か陸稲が入る場合は残効が 問題となるが，スギナの発生盛期の散布では被害はな く,これによつてスギナは地下茥まで枯死するので, 完
全防除が可能であると考える。ただし除草体系として は, 播種直後にリニニロンを a 当り $10 \mathrm{~g}$ 散布し, 他の 雑草をおさえ，のちに前記の薬剤を使用することにな る。

\section{摘 要}

（1）スギナの生態について調查した。

（2）胞子の発芽試験を 5 月の室温で試みた。接種後 7 日目に一斉に発芽し, 43 日後には栄養茎の発生がみ られる。

（3）地下茎の発根伸長は 4 月上旬より始まる。栄養 茎の最も繁殖するのは地下 $30 \mathrm{~cm}$ 以内の地下茎からであ る。

（4）栄養茎は一節さえあれば発根可能である。スギ ナの生育は $\mathrm{N}$ によつて左右される。 $\mathrm{pH}$ は 7 前後がよ かつた。発生深度は 5 10 cm がよい。土性は壤土がよ かつたが，土壌中の養分， $\mathrm{pH}$ なども関係すると考えら れる。

（5）地下茎の繁殖力は旺盛で，1年で総重は 33〜 37 倍, 長さは 165〜182 倍となる。

（6） スギナの防除は，麦畑の場合，跡作のない時は スギナ発生期から麦朾取り 15 日前の間に, $\mathrm{a}$ 当りリニ二 ロン $10 \mathrm{~g}+2$, 4-D $20 \mathrm{~g}$ の混合液をスギナの草体に散布 すればよい。間作や跡作に大豆，陸稲がある場合は，残 效の問題から，スギナの発生最盛期頃に散布することが 必要である。 


\section{引用 文 献}

1) 牧野富太郎：新植物図鑑北隆館 (1963).
2) 行方沼東 : シダの採集と培美 (総頁数 357), 加島書店 (1963).

3）川島良一・好山宣重：A T A 飞上る烟地の多管生雑草防除. 雑 草研究 2, (1963).

\title{
Ecology and Chemical Control of Field Horsetail (Equisetum arvense L.)
}

Nobuo Nihei, Tohru Sasaki and Shin-ichi Yamazaki

Furukawa Branch Station, Miyagi Prefectural Agricultural Experiment Station, Furukawa, Miyagi

\section{Summary}

Auto-ecology of field horsetail was surveyed from the standpoints of emergence from spore, elongation of subterranean stem, emergence of root from vegetative stem, depth of emergence, effect of soil $\mathrm{pH}$, effect of fertilization and so on.

For the purpose of the control of this weed in barley or wheat fields, the application of linuron and $2,4-\mathrm{D}(100 \mathrm{~g}+200 \mathrm{~g}$ in a. i. per $10 \mathrm{are})$ at the times between vigorous emegence stage of this weed and 15 days before the harvest would bring a good result. When next crop cultivation will be expected, the former application time should be selected.

\section{ヨモギの生理生態およびその防除法に関する研究}

\section{第 2 報 種子繁殖について}

\author{
九州大学農学部作物学教室 伊藤健次 - 井手欽也 - 开之上準
}

\section{1.は じめに}

ヨモギが種子より発芽し生長しても，その個体から地 下茥の発生がなければそれ 1 個体で一生を終つてしまう ことになり，実生のヨモギは 1 年生雑草としての重要性 しかもたないであろう。しかし実生個体も地下茎を発生 するとすれば，しない場合にくらべて，その雑草として の害は著しく大きなものとなることは明らかである。

そこでこの点を確かめるために，種子による繁殖につ いての実験をするに先立ち, 次のような処理を試みた。

ファイトトロンの $20^{\circ} \mathrm{C}-15^{\circ} \mathrm{C}$ でヨモギの実生個体を 育て, 播種 60 日後 (葉数 17 枚, 草丈 $15 \mathrm{~cm}$ ), 苗の茎 基部に子葉節より $1 \mathrm{~cm}$ 上まで培土した。処理 10 日後 に茎の基部より培土を除去し観察したところ, 茎基部の 腋芽が培土後地下茥となつて伸長し, 最大 $5 \mathrm{~cm}$ に達し ていた（第 1 図）。一方無処理区の個体では，茎基部の 腋芽が分枝としてわずかに $4 \sim 5 \mathrm{~mm}$ ぐらい伸びている 程度であつた（第 2 図）。

このよらにヨモギの実生個体が地下茎を発生するとい ら事実は，1年間にヨモギ種子 1 粒から数個体ないし数
十個体のヨモギが育つことを意味し，またヨモギ個体は 主に地下茥で越冬することを考えると，1年生から多年 生雑草になることをも意味する。自然条件下ではヨモギ の実生傴体の茎基部が土中に埋まることは当然起こりう ると考えられるところから，ヨモギの繁殖においては種 子による繁殖様式もかなり重視する必要があるのではな いかと考えられる。以下ヨモギの開花結実および種子の 発芽などについて行なつた実験結果について報告する。

\section{2. 実験および調査とその結果}

\section{(1) 開花と稔実}

\section{1）ヨモギの開花と日長}

材料には草丈 $10 \mathrm{~cm}$, 葉数 8〜10 枚の実生個体および 地下茎の先端が伸長して地上に出芽し同じぐらいの大き さにまで生長した個体を用いて，7月 12 日より短日処 理 (8 時間日長) と 長日処理 (補光 - 昼光色螢光灯 $10 \mathrm{~W}$ 1 個，植物体より $1 \mathrm{~m}$ 上方）を行なつた。

その結果, 短日区は実生個体抽よび地下茎からの個体 ともに, 処理開始 24 日後に最初の花蕾が出現し, 40 日 後には花粉がとび始めた。なおこれら短日区の個体の草 